\title{
An Observational Study on Forest Landscape Conservation in Malaysia via the Establishment of Forestry Educational Centres
}

\author{
"Mohd Kher Hussein, Mohd Johari Mohd Yusof and Nor Syuriaty Jaafar
}

First submission: 16 May 2019; Accepted: 20 March 2020; Published: 15 December 2020

To cite this article: Mohd Kher Hussein, Mohd Johari Mohd Yusuf and Nor Syuriaty Jaafar (2020). An observational study on forest landscape conservation in Malaysia via the establishment of forestry educational centres. Journal of Construction in Developing Countries, 25(2): 153-173. https://doi.org/10.21315/jcdc2020.25.2.6.

To link to this article: https://doi.org/10.21315/jcdc2020.25.2.6

\begin{abstract}
The establishment of the forestry educational centre is a good effort made to protect and conserve the forest as well as assisting the public in understanding the landscape changes and sensitivity towards its sustainability. However, there are lacks of consciousness and obligation of the important of landscape conservation in the context of development planning that causes the problem of effective implementation of a conservation strategy exists. Therefore, this paper aims to discuss forest landscapes conservation, particularly in Malaysia with the objectives of to analyse the current landscape features of selected forestry educational centres and to increase awareness among the stakeholders on the importance of conserving and preserving forest landscape towards its sustainability. The study was conducted using two methods specifically via a case study where the Sultan Idris Shah Forestry Education Center (SISFEC) was selected and field observations were conducted to analyse the existing physical condition of the study site. Findings have indicated that SISFEC has successfully conserved the existing landscapes and delivered awareness and knowledge on forest conservation and preservation to the public through several activities such as forestry camps, nature walks, and environmental education programmes. On the other hand, the findings also suggested that the forestry management should give higher priority in maintaining the manmade landscape image of the forest and plan their activities well through good monitoring and efficient management planning which will ensure the site's sustainability in future.
\end{abstract}

Keywords: Forest, Landscape, Education, Conservation and sustainability

\section{INTRODUCTION}

Malaysia's forest landscapes are unique and have attracted people of all ages from all over the world to appreciate it. Currently, $59.5 \%$ of Malaysia's lands are covered by forest (WWF [World Wide Fund for Nature] Malaysia, 2019). Nonetheless, deforestation is still a major concern in Malaysia which causes landscape deterioration since the country is still rapidly developing. Between the years of 1983 and 2003, Malaysia has lost their forest cover of about 4.9 million hectares (WWF Malaysia, 2019). Hence, in order to prevent this matter from becoming a major issue; a National Forestry Policy has been strengthened by the government in terms of relationship and cooperation between the federal and state governments in developing any of the forest area (Forestry Department of Peninsular Malaysia, 2019). One of the aspects included in this policy is the declaration of Permanent

Department of Landscape Architecture, Faculty of Design and Architecture, Universiti Putra Malaysia, Serdang, Selangor, MALAYSIA

*Corresponding author: mohdkher@upm.edu.my 
Forest Reserve (HSK) for sufficient areas which are strategically located throughout the country, based on the concept of rational land use. In line with this, HSK have been classified into four main functions which are Protection Forests, Work Forests, Amenity Forests and Research and Education Forests (Forestry Department of Peninsular Malaysia, 2019).

Under this National Forestry Policy, Research and Education Forests has been introduced for research, education and preservation of biological diversity. The aim is to promote education in forestry and handle publicity services and development to enhance the understanding of the forest benefits. Furthermore, it addresses issues raised by the international community on the importance of biodiversity conservation and utilisation of genetic resources and the role of local communities on the development of genetic resources and the role of local communities on forest development. In addition, the policy noticed that the public should be prepared with forest knowledge and environment so that they could effectively participate and become involved in matters concerning forest conservation.

However, a problem was detected where there are lacks of consciousness and obligation of the important of landscape conservation in the context of development planning that causes the problem of effective implementation of a landscape conservation strategy exists for forestry educational centres. Therefore, this paper aims to discuss forest landscapes conservation, particularly in Malaysia with both objectives to analyse the current landscape features of selected forestry educational centres and to increase awareness among the stakeholders on the importance of conserving and preserving forest landscape towards its sustainability.

At the same time, no doubt, the remaining forests need to be conserved due to the benefits and advantages it could offer. An adequate planning pertaining to forest management by relevant authorities should be strictly adhered to, so that forests could be sustained for future generations (Adzidah and Izawati, 2015). Hopefully, the establishment of forestry educational centres can help people understand more about the landscape changes and sensitivity as well as protecting and conserving their environment towards sustainability. Currently, there are two forestry educational centres in Klang Valley namely the FRIM (Forest Research Institute Malaysia) and the Sultan Idris Shah Forestry Education Center (SISFEC) both located in Kuala Lumpur. FRIM is one of the top ecotourism destinations in Malaysia, offering visitors various attractions and activities such as nature trails, waterfalls, nature education centre, camping and picnic sites, botanic gardens and arboreta (FRIM, 2019). Meanwhile, SISFEC is a permanent forest reserve that was awarded to Universiti Putra Malaysia (UPM) through a long-term agreement by the Selangor state government which lasts 80 years. It was placed under the responsibility of the Faculty of Forestry, UPM to conduct activities in relation to education, research and development in the field of forestry.

SISFEC have been selected for this study because it is the newest forestry educational centre in Malaysia and has become an educational reference centre, research and development centre for good practice in conservation of tropical forest management at national level and globally. This centre acts as an outdoor laboratory for students to develop skills in forest management and to gain more knowledge and skills in classifying trees and plants, learning soil science, tree inventory, silviculture, ecology, wildlife, outdoor recreation and eco-tourism. The forest's original area covered 4,270.7 hectares which was gazetted as a closed forest reserve in 1906; however, the size has since dropped to 1,176.1 hectares due to rapid development and industrialisation activities. Awang Noor et al. (2007) 
claimed that it has lost almost $68 \%$ of its forested area within 14 years from 1983 to 1997.

This study would provide an understanding and increase awareness to the construction industry players of developing countries on important to conserving the remaining forest. Forestry educational centres were developing through the concept of sustainable development or green technology. This concept is environmentally friendly and being used in a way which does not disturb the environment and does not destroy natural resources. On the other hand, construction industry players can also learn on how the green technology are applied to forestry educational centres of products applications, equipment and systems used to conserve the forest environment and resources, which minimises and reduces the negative impact on human activities.

\section{THE IMPORTANCE OF THE STUDY}

This study highlighted four aspects that need to be incorporated in the development planning for landscapes conservation of forestry educational centres. Firstly, biodiversity promotion and wildlife protection, secondly, Earth protection from harm activities, thirdly, human health and lastly, cultural heritage. On other aspect, this work contributes to the current knowledge of landscape conservation by providing a simple tool for scrutiny landscape conservation activity. It provides a checklist of field activities during field observation and developing conservation criteria that need to be monitor on the site study. This novel protocol is a new idea that requires further testing and it may help trigger wider participation in landscape conservation and restoration, particularly by local communities, conservation and management stakeholders, academic and educational initiatives and citizen scientists.

Moreover, this study informs the related stakeholders that any designs wanted to be planned in forestry educational centres must be in harmony with natural forest landscapes and considering their own unique features that highlight the forest identity as well as the cultural heritage. Design of buildings and other structures (e.g., walkway, bench, signage, shelter, etc.) must be visually in harmony with the surrounding. The most important consideration was that the structure and building designs in forest educational Centres must highlight aspects of the surroundings.

This study also helps people of all ages understand and appreciate our country's forest landscapes and how to conserve those resources for future generations. Also, this study provides the public knowledge to understand forest landscape issues and the skills to participate meaningfully in the debates that surround them. It also helps people develop the critical thinking skills and the knowledge they need to understand the complexities of ecological issues. The most important thing is this study encouraging people to take personal responsibility for their relationship with the environment.

\section{LITERATURE REVIEW}

A literature review has been carried out to discuss published information in a subject area of forest conservation, forest landscapes and forestry educational centres. This activity highlighting what has already been done, what is generally accepted and what is emerging of thinking on the forest landscapes topic. 


\section{Forest Conservation}

We need to conserve our forests because of the various benefits forests provide which include land conservation, securing of water sources, control of climate change, and creation of natural environs essential to human existence (Pawar and Rothkar, 2015). Furthermore, humans and other living things such as wildlife need the forests not only for their exceptional biodiversity, but also as carbon stocks and as green bridges to a future with lower emissions to keep global warming within tolerable limits (KfW Bankengruppe, 2010). But, bear in mind that nowadays, forests are being destroyed thus we should take concrete action to conserve our forests as they are unique and irreplaceable resources for the future. Fortunately, the Malaysian government has given its full support and commitment to protect our forests from diminishing. For example, the government has developed the national policy on Biological Diversity 2016-2025 where the policy statement is "Malaysia is committed to conserve its biological diversity, promote its sustainable use and ensure fair and equitable sharing of the benefits arising out of the utilisation of genetic resources".

In conserving Malaysia's forest, two approaches had been implemented by the authority namely "in situ conservation" and "ex situ conservation" (Lee et al., 2001). In situ conservation means maintaining natural plant habitats for conserving genetic diversity. This approach is a much cheaper and easier method to implement. However, it required a network of totally protected areas including national and state parks, wildlife and bird sanctuaries, and the Permanent Forest Estates (PFEs) which includes the forestry educational centre under this approach. Meanwhile, ex situ conservation means maintaining species outside their original habitats in botanical gardens, arboreta, seed gene banks, in vitro gene banks or field gene banks. It is an important technique for long-term storage of genetic material for breeding programmes or for reintroducing species to the wild.

Forest conservation activity is a strategy for sustainable forest management. Due to that, several criteria for the conservation had been developed to meet the needs of present and future generations. The Canadian Council of Forest Ministers (CCFM) has developed the national criteria and indicator for forest sustainability. These are used for national reporting on sustainable forest management (SFM) and by the Canadian Standards Association in its forest certification system. The following are seven SFM criteria in the Montreal Process:

1. Conservation of biological diversity.

2. Maintenance of productive capacity of forest ecosystems.

3. Maintenance of forest ecosystem health and vitality.

4. Conservation and maintenance of soil and water resources.

5. Maintenance of forest contribution to global carbon cycles.

6. Maintenance and enhancement of long-term multiple benefits to meet the needs of societies.

7. Legal, institutional and economic framework for forest conservation and sustainable management. 
While, the Malaysian criteria of SFM are as follows (Rabiul et al., 2010):

1. Enabling condition for sustainable forest management.

2. Forest resource security.

3. Forest ecosystem health and condition.

4. Flow of forest produce.

5. Biological diversity.

6. Soil and water.

7. Economics, social and cultural aspects.

Criteria and indicators are important because it helps to clarify the scope, key elements and measurable features of sustainable forest management. It is also as a step towards a set of rules for forest management in forest products. Indirectly, it helps in protecting the forest landscapes from destruction and increase awareness to the stakeholders.

\section{Forest Landscapes}

The term landscape is very broad. It covers scenery, painting, trees, wildlife, gardens and places. However, the term expands in meaning, particularly when the fields of environmental design such as landscape architecture began to take a serious interest in landscapes. The term has transformed into valuable meaning as a "composition of man-made or man-modified spaces to serve as infrastructure or background for our collective existence" (Jackson, 1984). Then it has evolved as an area, as perceived by people, whose character is the result of the action and interaction of natural and/or human factors (Council of Europe, 2000). Currently, the Environment Foundation of New Zealand (2018) has mentioned that the New Zealand Environment Court had suggested the definition of landscape as "the natural and physical attributes of land together with air and water which changes over time and which is made known by people's evolving perceptions and associations (such as beliefs, uses, values and relationships). Landscape considers the overall composition, spatial structure and aesthetic values of an area as well as its meanings and associations for different segments of society including the sense of place and identity that communities attach to their local environs".

Hence, forest landscapes are dynamic and very sensitive to human disturbance. Their landscapes are made up of landforms, mountains, hills, plains, and plateaus as well as lakes, streams, soils and natural vegetation (National Geographic, 2019). These landscapes can also range from large continuous areas of forests used for multiple purposes (production, cultural, recreational or environmental services and the like) to mosaics of forests and blocks of trees within the rural landscape (Dewees et al., 2011). According to Stepankova, Bihunova and Kabai (2012), forest landscape is a dynamic complex of plant, animal and microorganism communities and their biotic environment interacting as a functional unit, where trees are a key component of the system, interact with one another and with the non-living part of the environment - including the soil, water and minerals. 
Clearly here, the attributes of a forest landscape consist of biophysical elements, patterns and processes, sensory or perceptual qualities (e.g., scenic landscape or the distinctive smell and sound of the coast) and associative meanings and values as well as spiritual, cultural or social associations (such as heritage sites and popular walking or fishing spots).

The complexity of forest landscapes must urge us, as humans, to protect it from degradation. This is because forest landscapes enable us to reconnect with nature, refresh our minds and to gain a greater appreciation of our natural heritage. Forest landscape also plays an important role in directly supporting the ecotourism industry for the country. Table 1 shows the importance of landscapes that contributes significantly to human well-being and their quality of life.

Table 1. Importance of Landscapes

\begin{tabular}{lll}
\hline Economic & Social/Cultural & Ecological \\
\hline Tourism & Cultural values & Indigenous habitats \\
Branding & Quality of life & Regeneration \\
Attracting investment & Spiritual renewal & Conservation \\
Attracting residents & Sense of place and identity & \\
Productive capacity & Historical linkages & \\
\hline
\end{tabular}

Therefore, due to the high contribution of landscape to human life, we need to educate people on how to preserve and conserve them from degradation. Hence, the establishment of the forestry educational centre is a good step in ensuring their existence and to educate people about forest environment. However, in developing this forestry educational centre, responsible authorities need to have a proper development planning. They also need to understand and enhance a harmonious design for the buildings in the park. An investigation on the economic and cultural impacts as well as ecosystem loss should also be understood, too. Meanwhile, the education and outreach programmes should be able to inform stakeholders, researchers and the general public regarding forest health issues, best practices and opportunities to connect through participatory research networks.

\section{Forestry Educational Centre}

Forestry educational centre is closely related to environmental education. UNESCO-UNEP (United Nations Educational, Scientific and Cultural OrganizationUnited Nations Environment Programme) (1994) had highlighted the definitions for environmental education as follows:

1. The Nevada Conference of the International Union for the Conservation of Nature and National Resources (1974): Environmental education is the process of recognising values and clarifying concepts in order to develop skills and attitudes necessary to understand and appreciate the interrelatedness among man, his culture and his biophysical surroundings. It also entails practice in decision-making and self-formulating of code of behaviour about issues concerning environmental quality. 
2. Organization of American States Conference on Education and Environment in the Americas (1971): Environmental education is the activity that involves teaching about value judgment and the ability to think clearly about complex problems-about the environment-which are as political, economic and philosophical as they are technical.

3. United States Public Law 91-516, the Environmental Education Act: Environmental education is educational process dealing with man's relationship with his natural and man-made surroundings including the relation of population, pollution, resources allocation and depletion, conservation, transportation, technology and urban and rural planning to the total human environment.

Based on the definitions, forestry educational centres can be understood as a place where it provides environmental education facilities where the community, teachers and students can visit to learn more about the forest environment, its importance and what people can do to help protect it. This centre promotes conservation of the landscapes, including natural ecosystems, education focusing on forest stewardship, and research related to forest ecology and management. This centre provides people like teachers and students with the opportunity to engage with forest environments to explore forest systems and the links between humans and natural environments. At the same time, it offers the researchers to conduct a research related to forest landscape environment such as green technology that deals with using science and technology to conserve nature, and to remedy the negative impact that humans have on it.

Nowadays, the landscapes of the forestry educational centre have experienced vast changes. Many facilities have been built in this type of forest to cater to the needs of the user. Previously, only natural landscapes could be found around the forest, now, however, many manmade elements have been constructed and built. Hence, the related forest authorities should pay attention at the early stage of the forest development by carefully focusing on its preservation, conservation, protection of natural systems and maintaining its nature for their sustainability. The design of structures or buildings needs to be harmonised with the surrounding natural landscape setting. Furthermore, landscape architectural elements such as shelters, benches, signage's, information boards, roads, bridges, walkways, picnic tables and stairs should portray the forest's local identity and whether it is in harmony with the sense of place. The design should indicate a good combination of a natural environment and architectural characteristics, for example, application of vernacular architecture. The designs should also be visually in harmony with the surrounding natural forest environment and concerns in terms of its form, colour, materials, landscape degradation, preservation of natural processes, and protection of biological diversity.

Furthermore, concerns on whether the developments of those manmade landscapes are harmonised with forest environment were also raised and whether the proposed forest identity was leading towards sustainability or not. It was argued that as much as the natural environment contained in the forests, the built environment influences the visitors' experience and impressions about how the management fulfils its mission of stewardship. This means, the landscape designs, especially the design of these many facilities in forest education centres must fit with the forest setting, carefully constructed and meet user's needs. This also shows 
that the landscape architectural identity of forestry educational centres is a very important matter to maintain the spectacular scenery and landscape settings of that forest as well as to conserve a natural resource, which would later provide good learning experiences and knowledge to the public.

\section{CONCEPTUAL STUDY FRAMEWORK}

Forest conservation is the practice of planting and maintaining forested areas for the benefit and sustainability of future generations (Pawar and Rothkar, 2015). Meanwhile, landscape conservation is an activity to preserve, conserve, rehabilitate and protect as well as manage the natural environment from destruction (Mohd Kher and Noorizan, 2007). Both practices have similar principles which are to ensure that the natural resources are being managed in sustainable ways to meet a balanced environment and ecologically with the goal to satisfy the needs of human kind and all living things on Earth.

The study framework was based on firstly, literature, where the relevant theoretical concepts are reviewed. The topics of forest conservation, forest landscapes and forestry educational centres as well as the best practice guidelines for forest landscape development are reviewed and analysed. Secondly, a field study was conducted to evaluate the conditions of the forestry educational centre by taking SISFEC as a case study for a clearer picture of what is happening on site. A documentary survey from published and unpublished sources such as maps was carried out for more detailed information on the study area. Reports and articles on related studies available were also consulted for this purpose. Lastly, conclusions were formulated to conclude the findings. Figure 1 is a summarisation of the study framework.

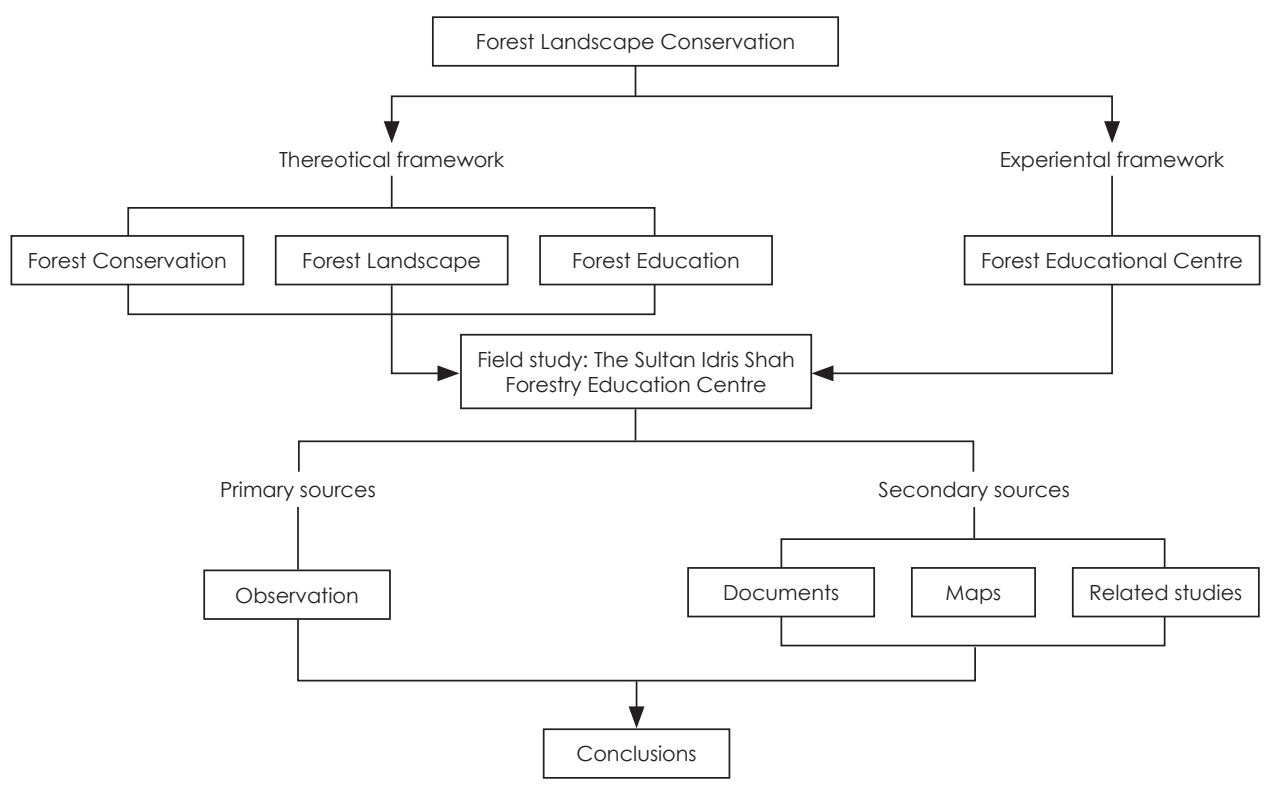

Figure 1. The Study Framework 


\section{RESEARCH METHODOLOGY}

This study applied two methods. Firstly, it involved a case study where SISFEC was selected. Case studies were used because they are applicable to real-life, contemporary, human situations which allowed researchers to explore and investigate the contemporary real-life phenomenon through detailed contextual analysis of a limited number of events or conditions, and their relationships. Furthermore, it allowed the researchers to go beyond the quantitative statistical results and understand the behavioural conditions through the actor's perspective (Zaidah, 2007). Yin (1984) defined the case study research method "as an empirical inquiry that investigates a contemporary phenomenon within its real-life context, when the boundaries between the phenomenon and context are not clearly evident and in which multiple sources of evidence are used". Thus, this study tries to explore and investigate the establishment of forestry educational centres as a strategy to conserve forest landscapes from destruction and diminishing. This method enables researchers to closely examine the data within a specific context (forestry educational centre).

Secondly, field observations. This method has been chosen for collecting data about people, processes, and cultures (Kawulich, 2012) and provides the systematic description of the events, behaviours, and artefacts of a social setting (Marshall and Rossman, 1989). Through observations, it allows researchers to gain first-hand experience and knowledge about the conservation processes being taken to conserve forests in Malaysia. It also enables a greater understanding of the intricacies and complexities of conservation activities. Features that were observed were the forestry development sensitivity towards the existing environment. For instance, biodiversity conservation (trees cutting, afforestation, wildlife, etc.), soil, topography and water condition (landslide prevention, flood prevention, water quality, etc.), cultural landscapes (settlement, human activities, etc.) and manmade elements (buildings, structures, etc.). Maintenance aspect were also being observed to see whether the site has put a priority in providing a high experience quality to the user's and enhance a good appearance of the site. Photographs were taken during this field observation as evidences of visual assessment regarding current status of landscape conservations on the study site. Table 2 is the checklist for the field activity of this study.

Table 2. Checklists of Field Activities

\begin{tabular}{ll}
\hline Observation Aspect & Things to Observe \\
\hline $\begin{array}{l}\text { Biodiversity } \\
\begin{array}{l}\text { Soil, topography and water } \\
\text { body }\end{array}\end{array}$ & Vegetation; Tree cutting; Afforestation \\
Wildlife & Birds; Mammals; Insects; etc. \\
Manmade elements & Buildings; Structures (signage, stairs, etc.); Design \\
& aspects (color, material, form, etc.); Green technology \\
Cultural heritage & 1. Human intervention (trail, buildings, structures, etc.) \\
& 2. Human activities (agriculture, hunting, etc.) \\
3aintenance & Natural landscapes; Manmade landscapes \\
\hline
\end{tabular}


This study had established a criterion to evaluate whether forestry educational centres accomplishes the conservation criteria which are to preserve, conserve, rehabilitate and manage the natural environment from destruction. Those criteria are very important in ensuring the centres sustainability and confirming in fulfil the conservation criteria. Table 3 is the criteria used in this study.

Table 3. Conservation Criteria

\begin{tabular}{|c|c|}
\hline Criteria & Indicators \\
\hline Biodiversity & $\begin{array}{l}\text { 1. Vegetation in healthy condition, growth and in good } \\
\text { composition. } \\
\text { 2. No tree cutting occurrences. } \\
\text { 3. Carry out afforestation activity for vacant area. } \\
\text { 4. Implementing silviculture technique. }\end{array}$ \\
\hline $\begin{array}{l}\text { Soil, topography and } \\
\text { water }\end{array}$ & $\begin{array}{l}\text { 1. No/minimal erosion happening. } \\
\text { 2. Keep a landform in existing condition/minimal alteration. } \\
\text { 3. Flood prevention. } \\
\text { 4. Water in good quality. } \\
\text { 5. Maintain existing water body. }\end{array}$ \\
\hline Wildlife & $\begin{array}{l}\text { 1. Variety of wildlife. } \\
\text { 2. Increased in number of birds, mammals, insects, etc. }\end{array}$ \\
\hline Manmade elements & $\begin{array}{l}\text { 1. Buildings are harmonised with surrounding environment. } \\
\text { 2. Structures (signage, stairs, etc.) blend with the surrounding } \\
\text { environment. } \\
\text { 3. Design aspects (colour, material, form, etc.) are sensitive to } \\
\text { existing environment and considered genius loci. } \\
\text { 4. Scales are appropriate and suited with natural character. } \\
\text { 5. Green technology application. }\end{array}$ \\
\hline Cultural heritage & $\begin{array}{l}\text { 1. The sites had shown a significant conservation on historical } \\
\text { values such as aborigine settlements/villages and war fort. } \\
\text { 2. The site kept maintaining the vernacular/traditional designs/ } \\
\text { arts on architectural buildings. } \\
\text { 3. Conserving the trails used by the aborigine for daily activities. }\end{array}$ \\
\hline Maintenance & $\begin{array}{l}\text { Carried out maintenance activity to ensure the site's cleanliness, } \\
\text { visual quality and plants health. }\end{array}$ \\
\hline
\end{tabular}

\section{RESULTS AND DISCUSSIONS}

A field observation was carried out in October 2018 at the SISFEC which is located in the Ayer Hitam Forest Reserve (as shown in Figure 2). It was launched by the UPM Chancellor, Sultan Sharafuddin Idris Shah on the 21st March 2012. This centre is located approximately $20 \mathrm{~km}$ from Universiti Putra Malaysia (UPM) Serdang, Selangor and $32 \mathrm{~km}$ from Kuala Lumpur. The centre landscape not only seems to be the refuge for many wildlife species especially small mammals and birds but is also a place that provides the populace in the Klang Valley as a green area for forest recreation. 


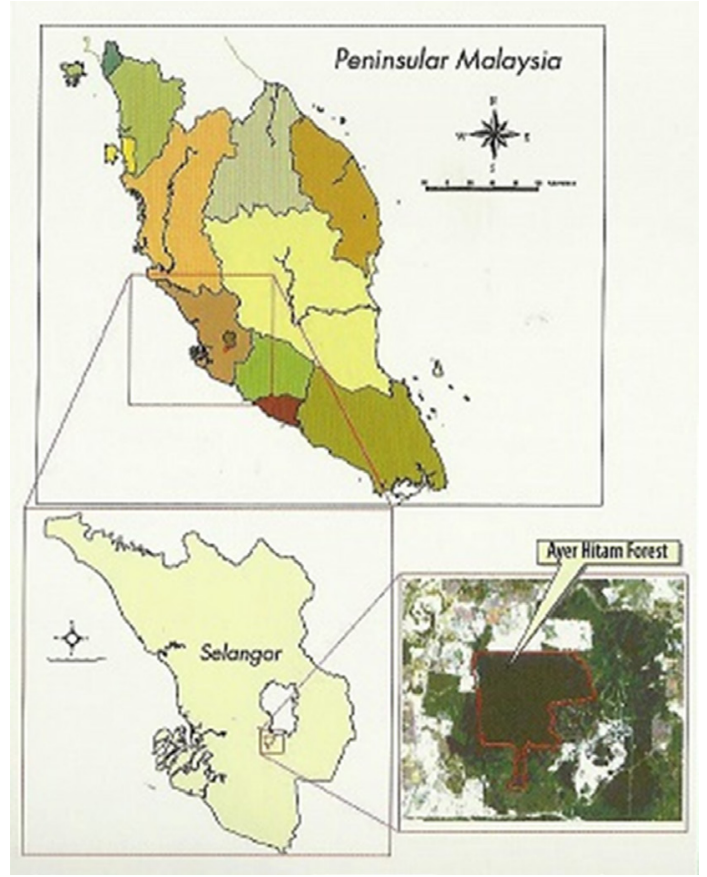

Figure 2. Location of SISFEC Source: Faridah-Hanum (2009)

Based on the observation, it was found that SISFEC has a valuable biodiversity of genetics, species and ecosystem levels. Its natural landscape has been conserved properly and kept in good condition (as shown in Figure 3) even though historically this site was selectively logged several times ago between the years of 1936 to 1965. According to Faridah-Hanum (2009), this forest is in the late stages of regeneration and fast reaching its climax. The remaining seedlings and saplings have reached timber size, and its natural landscape forest was classified as a disturbed KelatKedondong-Mixed Dipterocarp type of lowland forest (Faridah-Hanum, 1999). In 2015, it was reported that the site features some 430 flowering plant species, 33 fern species, 127 timber species and 99 herb species (The Star Online, 2015). Authors also noticed that SISFEC had implemented silviculture activities to ensure the health of their forest trees. Silviculture is the art and science of controlling the establishment, growth, composition, health, and quality of forests and woodlands to meet the diverse needs and values of landowners and society on a sustainable basis (Adams et al., 1994). Trees cutting were strictly not allowed in this area. Thus, it can be said that SISFEC has pleased the conservation criteria and indicators of biodiversity.

SISFEC had proved that human intervention in natural setting causes to environment degradation and losses of biodiversity as well as affect the beauty of the area previously. However, after the site being protected and conserved, the forest vegetations growth well and healthy as well as it still manages to retain a great deal of its original rainforest character that enhance back their biodiversity and beauty. Hence, the disaster landscapes forest can be rehabilitated if good planning and management being incorporated and implemented. 

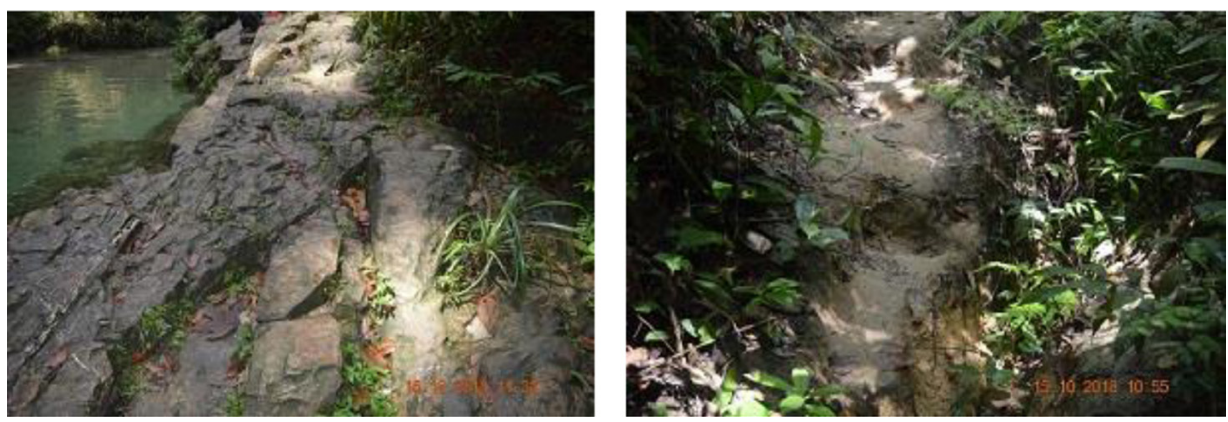

Figure 3. SISFEC Natural Landscapes

Based on the observation, it can also be seen that the topography of the forest is undulating with the slopes ranging between $10 \%$ and $20 \%$. With this slopes range, walking trails are suitable to be developed for all levels of users whose ages fall under Class 2, 3 and 4 walking trails (The Irish Sports Council, 2008). The slope was kept in a natural setting and untouched. Major erosion was not found. The forest is covered with igneous rock; the primary component is granite. The inner soil layer has metamorphic primary matter and ferro-magnesium as secondary matter. The soil series are classified as Serdang-Kedah and Serdang-Bungor-Munchong which consist of a combination of local alluvium formed by metamorphic rock (Ahmad Ainuddin et al., 2007). But, according to Mohammad Nazrin (2015), SISFEC has very acidic soil, highly weathered and poor in soil nutrient content due to soil management practice, parent materials and climatic conditions as well as types of tree growth in the area. Here, improvement on soil fertility can be abated by judicious planning measurements to create and perpetuate the critical components of forest stand structure and species composition (Misir and Misir, 2012). Here, an application of remote sensing and geographic information system (GIS) were recommended for analysing the watercourses, contours, soil classes, areas and conservation areas for sustainability and future development plan.

Through observation also, it can be seen clearly that SISFEC still contains an untouched river landscape enclosed by the surrounding hills and have not suffered great disturbance. The river water is crystal clear, and teeming with aquatic life like fishes, shrimp, algae and specialised flora. The rocks are not the typical granite boulders, but seem to be sandstone, forming slow moving streams with deep pools, white sand banks and small delightful (terraced) waterfalls throughout their length. The riverine flora is dominated by the elegant Dipteris lobbiana and a grass-like rheophyte. Three main rivers landscapes found in this area namely the Rasau, Biring and Nasih Rivers (as shown in Figure 4). However, the Nasih and Biring River have been severely compromised by land development. There is a pool along the Rasau River with a small waterfall known as "Blve Lagoon". The pool is $13 \mathrm{~m}$ deep and the colour of the water always changes according to the weather. During the rainy season, the water will turn a bluish-turquoise color, while during the dry season, the water is yellowish-emerald in colour. In another study, it was reported that the water quality of Rasau River is mainly in Class II which is suitable for recreational activity but needs treatment for water supply (Mohd Aizat and Mohamad Roslan, 2013). Here, soil, topography and water of SISFEC have accomplished the conservation criteria. However, as these attractive areas being open to the visitors for recreation, 
the management should comply with the carrying capacity for negative deterrent impact such as soil compactness, soil erosion and water quality causes by the visitors.
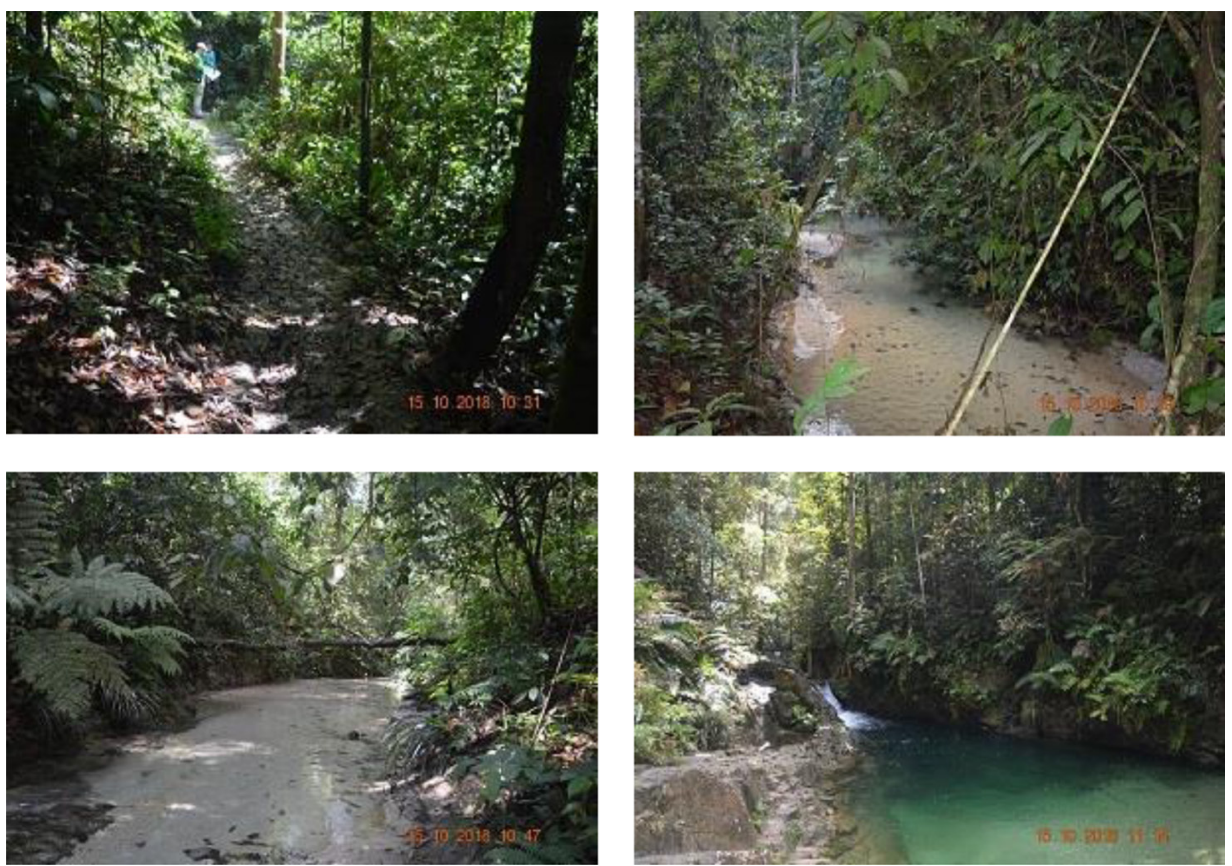

Figure 4. SISFEC Rivers

According to SISFEC staff and based on Figure 5, wild life such as the Malayan sun bear and panthers can be found here, as well as small mammals, such as leaf monkeys, macaques, a few gibbons, slow lorises, wild boars and various rodents. Some species of birds from 38 families, mainly fruit and insect eaters are found here such as Chesnut-naped Forktail, Puff-backed Bulbul and Collard Scops Owl (Mohamed and Abdul, 1999). In terms of insects, the largest number of species belongs to the order Hymenoptera. Other orders which have higher individuals are Collembola, Isoptera and Coleoptera (Sajap et al., 1999). The Star Online (2015), reported that SISFEC fauna include five of the 10 largest mammal species found in Peninsular Malaysia, 208 bird species including 35 endangered species and 30 migratory species, 14 small mammal species including the slow lorises, 13 bat species, 18 frog species, two reptile species and 10 fish species. Those figures show the variety of wildlife in SISFEC that tells us the success of conservation activity in the area. But to make sure these numbers continuously increase, it is necessary to provide training for the park's staff in community social relations and development in addition to scientific managing of plant and animal species and their habitats. This would be essential because their success depends on the relations between local people and the park staff (Muhumuza and Balkwill, 2013). In the meantime, enforcement on encroachment and illegal hunting should be strictly implemented to avoid further destruction. 

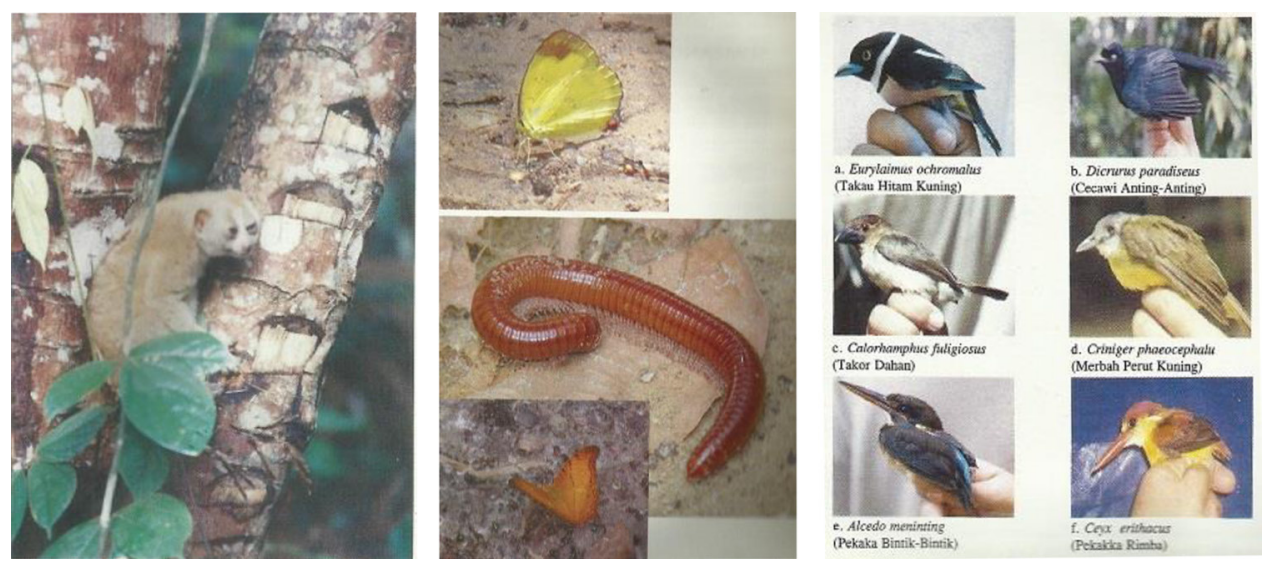

Figure 5. Amongst Fauna Found in SISFEC Source: Paiman and Amat (n.d.)

The authors noticed during the observation that the landscape of SISFEC has changed after it was gazetted as an Education and Research Forest. These changes were due to many manmade landscape elements being built to cater the needs of SISFEC's current function as an outdoor educational space. Amongst those elements are SISFEC's main complex, comprising four blocks which include administrative offices, lecture halls and laboratories for the purposes of teaching, conducting research as well as training (as shown in Figure 6). There is also an obstacle course circuit, chalets, camping sites and forest tree nurseries in supporting educational activities, especially for the Faculty of Forestry students. Based on an overall view, the manmade elements in this area were believed to have been built in respecting the existing environment.

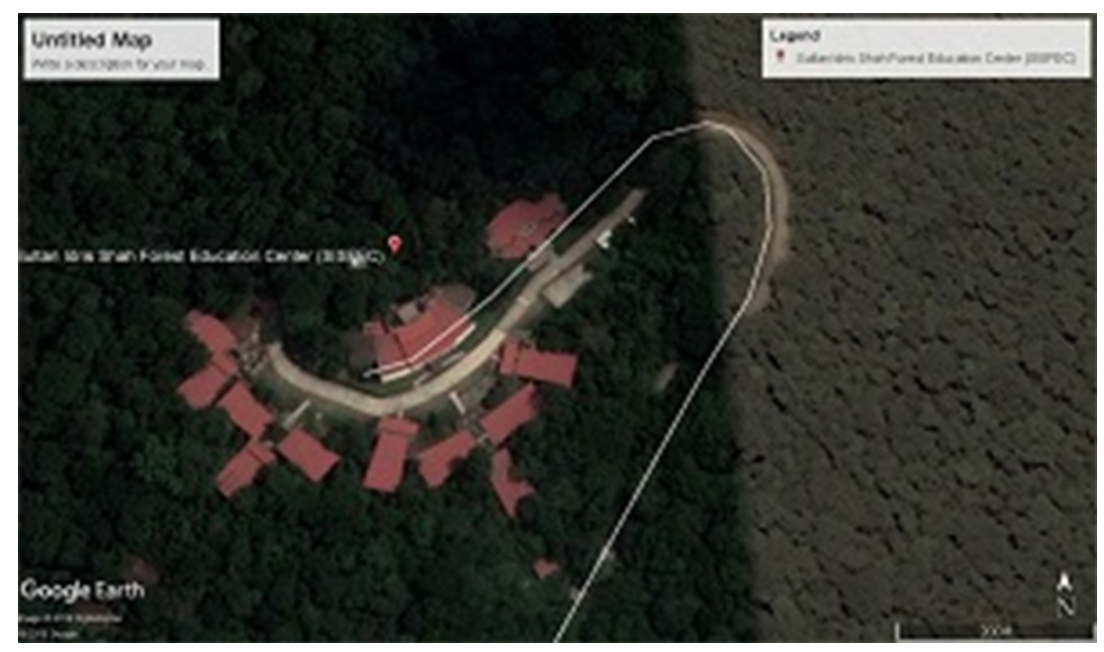

Figure 6. SISFEC Main Complex Layout

Source: Google Earth Pro (as retrieved on 8th March 2019) 
This can be seen on site where the management has put high priority in forest conservation during construction works on the facilities in SISFEC. Thus, the authors noticed that there were no tree cuttings as well as fieldwork being carried out at the built areas since the management applied a sustainable development or green technology concept. The footing system (as shown in Figure 7) was applied in building and manmade structures at certain parts and bridges (boardwalk) being built to connect each chalet at the lower areas. Furthermore, retaining walls were constructed along the roads to protect soil erosion. This shows that the management is very sensitive towards the natural environment and has minimised further disturbance. Indirectly, these efforts have protected the degradation of the existing landscape and enhanced the beauty of this area. It can be stated here that SISFEC has implemented a green design approach where the building design tries to minimise the harmful effects of construction projects on human health and the environment (Roy, 2008).
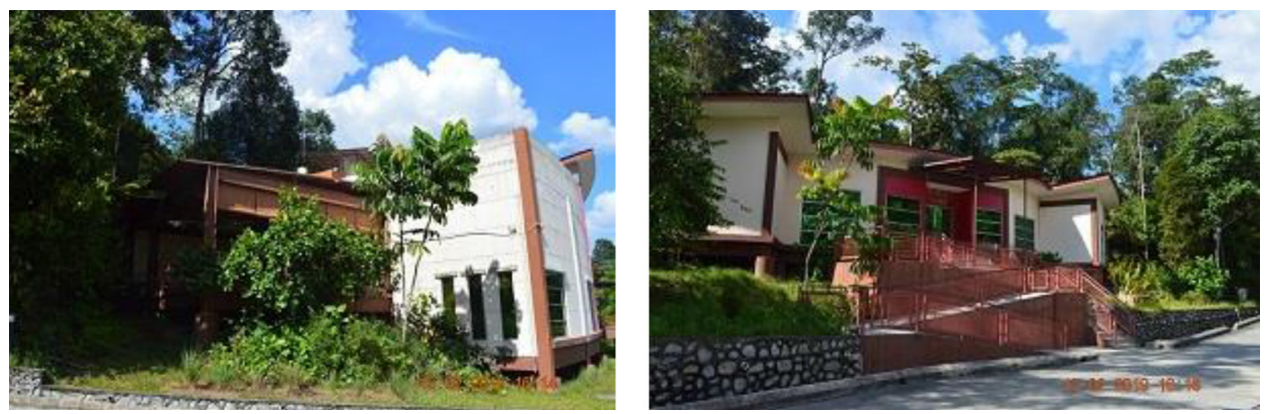

Figure 7. Footing System Applied to Building Construction

It was also observed that the architecture of the main complex was designed in modern forms that are innovative in construction technologies, particularly the use of glass, steel and reinforced concrete (as shown in Figure 8). Administration blocks and lecture halls were links with boardwalks. There is also an observation tower at the lecture hall for students to view the forest's panoramic scenery surrounding the building. Each block was equipped with Internet and Wi-Fi connections as well as closed-circuit television (CCTV) for security purposes. The public can see tall and big trees around these buildings as well as small vegetation growth untouched under the canopy. The authors believe that this design approach was to harmonise the building with its physical surroundings, enhance community awareness, while reducing environmentally polluting substances in achieving a balance between man and the surrounding features.

The authors also noticed that the roof design of new buildings in SISFEC were built in the mono pitch style with metal decking where it can be seen that the roof is a single-slope roof surface and is not attached to another roof surface. Unfortunately, the colour used for the roof lacked harmony with the surrounding landscape which is a bright red colour, especially when it is applied to the huge buildings. Red is always associated with energy, war, danger, strength, power, passion, desire and love which are less harmonious with the forest environment. This could threaten the small wildlife visually and provides visual contra to the existing environment. It is suggested here that in order to harmonise with the surrounding 
environment, chosen colours should be selected based on the surrounding forest setting and shall generally be darker than the landscape. Shades of brown and green are recommended; subdued greys may also be acceptable. Thus, some improvement needs to be done on colour selection for the buildings.
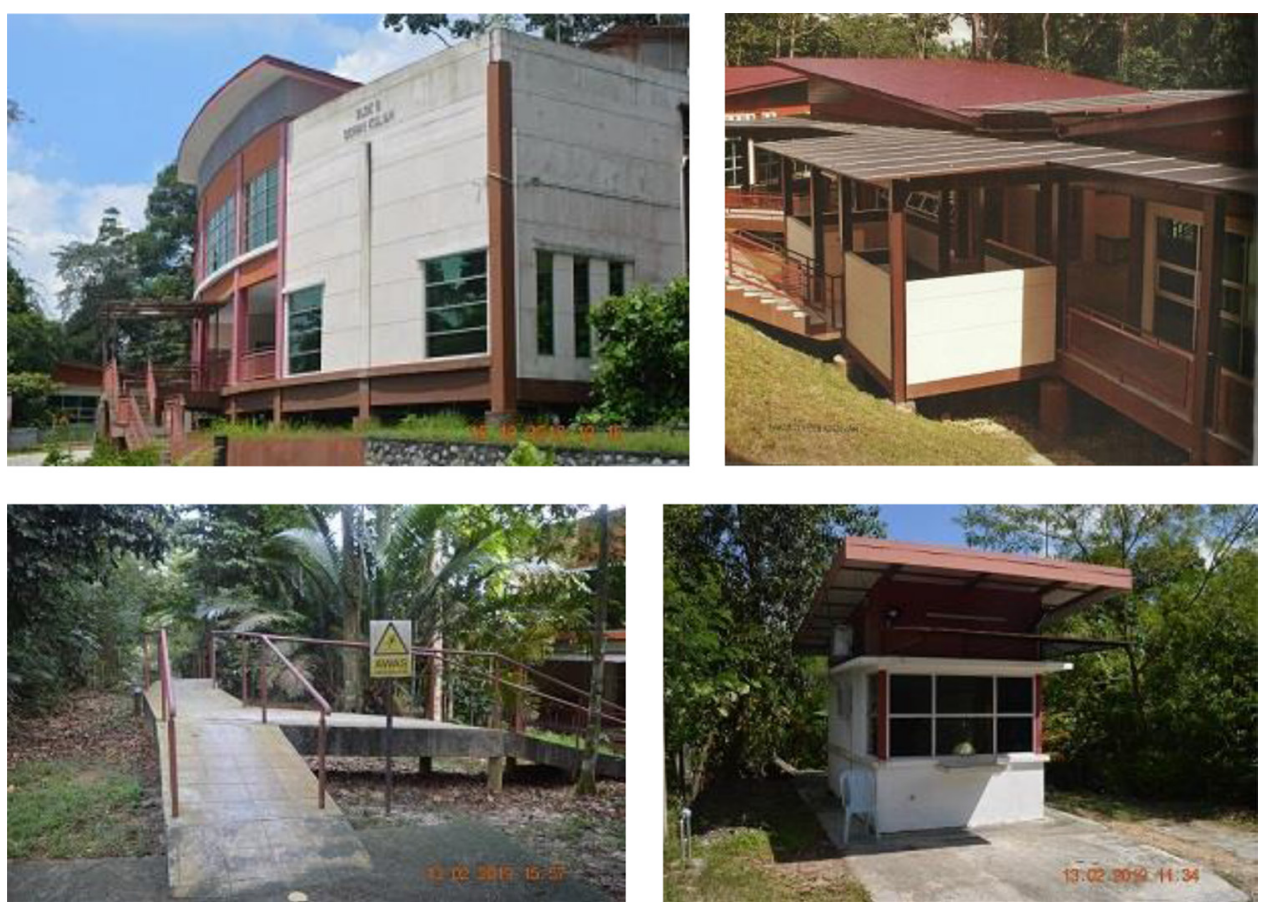

Figure 8. Modern Design of New Buildings in SISFEC

Apart from that, the authors noticed that the designs of chalets were influenced by Malay traditional architecture (as shown in Figure 9). This can be seen from the roofing form which is Bumbung Perak or "Dutch style roof ridge". However, this roof has been transformed into modern design where the slope of the roof is gentler, and the length of the eaves is also shorter. Modern materials such as zinc sheets were used rather than attap as well as concrete for the pillars. The application of traditional design is suitable with the surrounding environment since the materials used are available locally such as wood and bamboo (Zaimora, 2006). Thus, enhancing traditional design at the forestry educational centre may enhance the perception of appropriateness or harmony when colours are not in sharp contrast with natural landscape colours. 

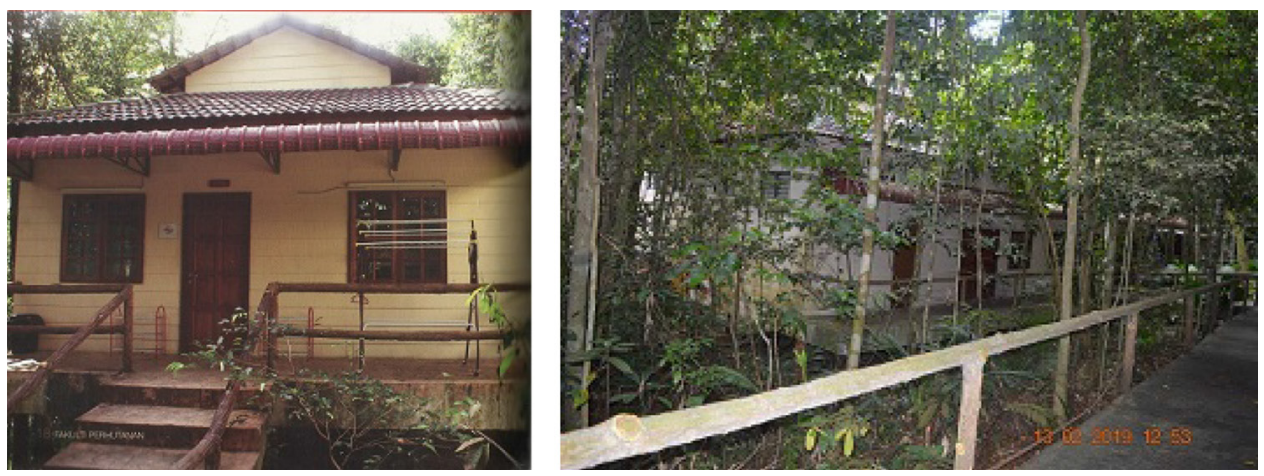

Figure 9. Chalet Design in SISFEC was Influenced by Malay Traditional Design

During the field observation, it was told by the SISFEC staff that the area has been resided by the Orang Asli of Temuan tribe who relied heavily on the forest resources for their living over 400 years ago. However, they have been relocated to a modern village situated in Taman Saujana Puchong bordering this study site which resulted to the township development (Paiman and Amat, 2007). However, their settlements still can be seen and some of them still being used as a transit station when they entered the site to search for the forest resources where permission were granted for them to do so (as shown in Figure 10). This had shown us that the park had a significant conservation on cultural heritage values on aborigine settlements/villages for future generations' acknowledgement. Since the aborigine settlements represent the work of man and nature, it is therefore important that they be conserved to give a sense of continuity with the past, as well as to provide a later option for use or reuse in the future.

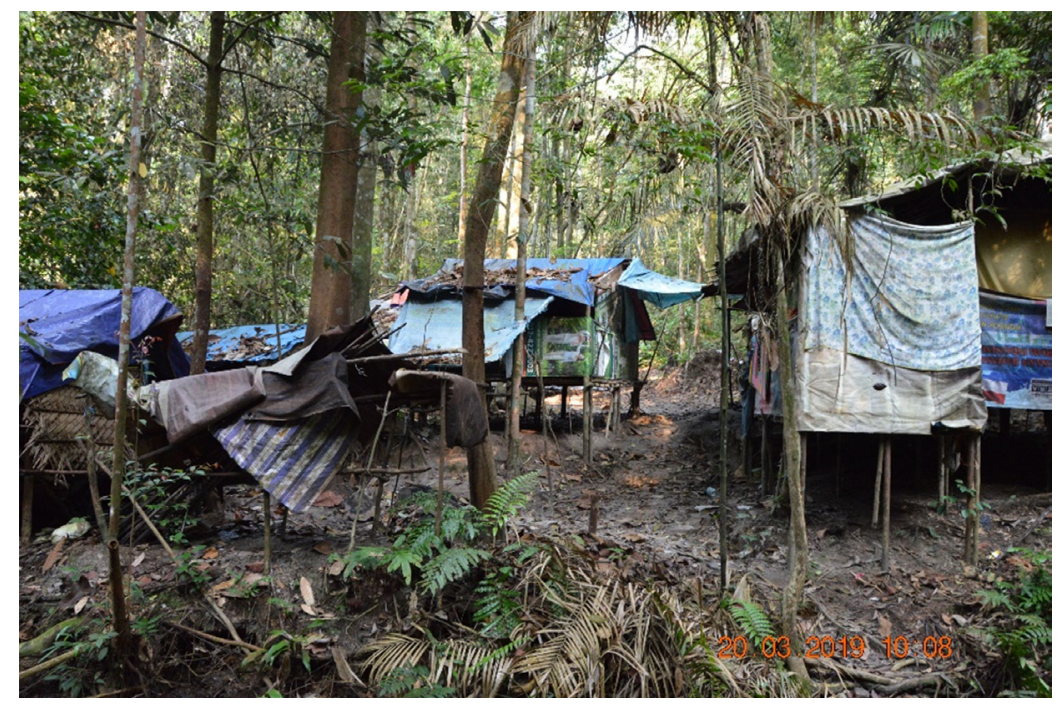

Figure 10. Temuan Tribe Settlement in SISFEC 
Finally, based on the authors' observation regarding the maintenance aspect, SISFEC management has put priority on daily site cleanliness especially at the main complex and along the roads. The activities encompass cleaning works (buildings, chalets and toilets), sweeping fallen leaves and throwing rubbish. Meanwhile, preventive maintenance was carried out for a deterrent of damages or curbing of damaged deterioration performed in a periodic schedule that is weekly, monthly or annually. Furthermore, corrective maintenance was done through repairing or changing all the damaged elements. However, some of the manmade elements such as benches and signage were in an abundant situation. Urgent action must be taken to avoid visual quality destruction. The management should be aware that what people see in the centre portrays the aspect of management and maintenance of the area. If the surrounding environments appear to be under good maintenance, it portrays the efficiency of the management planning. Furthermore, majority of the landscapes have been evaluated, appreciated and perceived according to situations with good maintenance functions as the enhancement (Nassaver, 1997).

\section{CONCLUSIONS}

Malaysia is fortunate in having vast areas of natural forests that are richer in plant species diversity and wildlife than other similar areas in other countries, such as South America. The remaining forested area, especially near to urban setting is vital to be conserved and protected. This is because forests have their own unique landscape character that must be conserved to ensure their sustainability for the present generation while maintaining their potential to meet the needs and aspirations of future generations. The four aspects that have been focused in this study are biodiversity promotion and wildlife protection, Earth protection, human health and cultural heritage are the major aspect that gives an impact to the successfulness of landscape conservation. Thus, those aspects are crucial to be focused in conservation activity.

This study provides information about the current qualities of the landscape and nature, which are nature or landscape potentials and their value as well as their sensitivity to impacts, the existing and potential impacts on these potentials, and the objectives of the forestry educational centres. With this information, the relevant authorities could prepare or improve on evaluation guidelines for the impact regulations and for the part of the environmental impact assessment which is concerned with the landscape and nature. This study also provides a basis for preliminary opinions about forestry educational centres in Malaysia.

Clearly, it is seen that the establishment of forest education, for example the SISFEC as a forestry educational centre is a noble effort from the government. This effort acts as a solution to the issue of fast diminishing landscape spaces and natural resources in our country. A most important thing was it sustains our infinite landscape spaces and natural resources from devastation. Furthermore, it also enhanced the biodiversity and protecting the wildlife as well as protecting the Earth from human harm activities. Indirectly it helps in increasing the human health and promoting the cultural identity of the local and provides a better future living condition and environment to the future generations. 
This study revealed that the management had put a high priority in their conservation activities to ensure the sustainability of this centre. Generally, the centre has accomplished the conservation strategy which is to protect, conserve and manage the environment in a sustainable way. It also fulfils the conservation criteria in terms of biodiversity, soil, topography, water, wildlife, manmade designs, cultural heritage and maintenance. Today, the centre has performed many functions which are not similar with monetary value. For instance, the centre conserves and protects the forest landscape, acts as a source of genetic material, as a wildlife refuge, for recreation space, and as carbon sink. SISFEC plays an important role in educating the public, especially students, in providing a greater sense of love and care for the environment as well as increasing school children's awareness on forest landscapes.

Nevertheless, the SISFEC management needs to pay extra attention and be serious in portraying the manmade landscape image because it can influence the visitors' experience. A good coordination and effort should be made to provide SISFEC with assistance in developing design themes and guidelines that can link visual quality of developed areas with the biological and physical well-being of the park landscapes. However, UPM as a high-quality provider of forest education has successfully managed this centre well in fulfilling its mission of stewardship.

Lastly, the authors believe that developing countries can learn from this study with regard to the establishment of forestry educational centres which has benefited the country and its citizens. This centre helps in developing a strong sense of conservation to the public on the value of forest protection whilst learning the uses of plants and timber around them. It would also inspire children and young people to value the biodiversity and habitats within their site. In short, the forestry educational centre is part and partial of the strategy in conserving the remains of forests, especially in urban areas around the world.

\section{REFERENCES}

Adams, D.L., Hodges, J.D., Loftis, D.L., Long, J.N., Seymour, R.S. and Helms, J.A. (1994). Silviculture Terminology with Appendix of Draft Ecosystem Management Terms. Bethesda, MD: Silviculture Instructors Subgroup of the Silviculture Working Group of the Society of American Foresters. Available at: http://oak. snr.missouri.edu/silviculture/silviculture_terminology.htm.

Adzidah, Y. and Izawati, W. (2015). Compromising forest environment in Peninsular Malaysia: The rights of public to environmental information. Malaysian Journal of Syariah and Law, 3: 1-24.

Ahmad Ainuddin, N., Hjortso, C.N., Norini, H., Khamurudin, M.N., Awang Noor, A.G. and Ismariah, A. (2007). Introducing stakeholder analysis in Malaysian forestry: The case of Ayer Hitam Forest Reserve. Pertanika Journal Tropical Agriculture Science, 30(2): 131-139.

Awang Noor, A.G., Norini, H., Khamurudin, M.N., Ainuddin, A.N. and Thorsen, B.J. (2007). Economic valuation of timber resources in Ayer Hitam Forest Reserve, Puchong, Selangor. Pertanika Journal of Tropical Agriculture Science, 30: 83-96.

Council of Europe (2000). The European Landscape Convention. Florence: Council of Europe. 
Dewees, P., Place, F., Scherr, S.J. and Buss, C. (2011). Investing in Trees and Landscape Restoration in Africa: What, Where, and How. Washington DC: Program on Forests (PROFOR).

Environment Foundation of New Zealand (2018). What are landscapes? Available at: $\quad$ http://www.environmentguide.org.nz/issues/landscape/what-arelandscapes/ [Accessed on 15 January 2019].

Faridah-Hanum, I. (2009). Ayer Hitam Forest. The Green Lung of Klang Valley. Selangor, Malaysia: Penerbit Universiti Putra Malaysia.

(1999). Plant diversity and conservation value of Ayer Hitam Forest, Selangor, Peninsular Malaysia. Pertanika Journal Tropical Agricultural Science, 22(2): 73-83.

Forestry Department of Peninsular Malaysia (2019). National Forestry Policy. Available at: https://www.forestry.gov.my/index.php/en/about-us/national-forestrypolicy [Accessed on 10 January 2019].

FRIM (Forest Research Institute Malaysia) (2019). Homepage. Available at: https://www.frim.gov.my/about-us/overview/ [Accessed on 20 March 2019].

Jackson, J.B. (1984). Discovering the Vernacular Landscape. New Haven, CT: Yale University Press.

Kawulich, B.B. (2012). Collecting data through observation. In C. Wagner, B.B. Kawulich and M. Garner (eds.), Doing Social Research: A Global Context. London: McGraw Hill, 150-160.

KfW Bankengruppe (2010). Conserving Forests to Protect Our Climate. Frankfurt: KfW Bankengruppe.

Lee, S.L., Sam, Y.Y., Marzalina, M. and Krishnapillay, B. (2001). Conservation, utilization and management of forest genetic resources in Malaysia. In Proceedings of the Southeast Asian Moving Workshop on Conservation, Management and Utilization of Forest Genetic Resources. Rome: Food and Agriculture Organization of United Nations. Available at: www.fao.org/3/ac648e/ ac648e07.htm [Accessed on 22 July 2019].

Marshall, C. and Rossman, G.B. (1989). Designing Qualitative Research. Newbury Park, CA: Sage.

Misir, N. and Misir, M. (2012). Modelling of soil erosion and its implication to forest management. In D. Godone and S. Stanchi (eds.), Research on Soil Erosion. London: IntechOpen. Available at: https://www.intechopen.com/books/ research-on-soil-erosion/modeling-of-soil-erosion-and-its-implication-toforest-management.

Mohamed, Z. and Abdul, R. (1999). Bird species composition in Ayer Hitam Forest, Puchong, Selangor. Pertanika Journal of Tropical Agricultural Science, 22(2): 95-104.

Mohammad Nazrin, A.M. (2015). Assessment of soil fertility status in different isolated land use types. MSc diss. Universiti Putra Malaysia.

Mohd Aizat, A. and Mohamad Roslan, M.K. (2013). Water quality index of selected stations at Sungai Rasau, Ayer Hitam Forest Reserve, Selangor. Proceedings of the International Forestry Graduate Students' Conference. Selangor, Malaysia: Faculty of Forestry, Universiti Putra Malaysia.

Mohd Kher, H. and Noorizan, M. (2007). Wetland landscape conservation and ecotourism in Malaysia. Pertanika Journal Social Science and Humanities, 5(2): 159-168. 
Muhumuza, M. and Balkwill, K. (2013). Factors affecting the success of conserving biodiversity in national parks: A review of case studies from Africa. International Journal of Biodiversity, 2013: 798101. https://doi.org/10.1155/2013/798101.

Nassaver, J.I. (1997). Placing Nature: Culture and Landscape Ecology. Washington DC: Island Press.

National Geographic. (2019). Landscape. Available at: https://www. nationalgeographic.org/encyclopedia/landscape/ [Accessed on 9 January 2019].

Paiman, B. and Amat, R.Y. (2007). Ayer Hitam Forest Reserve: Multimedia Super Corridor Community Heritage. Selangor, Malaysia: Faculty of Forestry, Universiti Putra Malaysia.

(n.d.). Hutan Simpan Ayer Hitam: Warisan Komuniti Koridor Raya Multimedia. Selangor, Malaysia: Faculty of Forestry, Universiti Putra Malaysia.

Pawar, K.V. and Rothkar, R.V. (2015). Forest conservation and environmental awareness. Procedia Earth and Planetary Science, 11: 212-215. https://doi. org/10.1016/j.proeps.2015.06.027.

Rabiul, I., Chamhuri, S., Shaharuddin, M.I. and Nurul Hidayah, C. (2010). Criteria and indicators for sustainable forest management in Malaysia. American Journal of Environmental Sciences, 6(3): 212-218. https://doi.org/10.3844/ ajessp.2010.212.218.

Roy, M. (2008). Importance of Green Architecture Today. New Delhi: South Asia Regional Initiative for Energy Integration. Available at: https://sari-energy. org/oldsite/PageFiles/What_We_Do/activities/SAWIE/SAWIE_11-2008/ SAWIE_11-2008/5.Importance\%20of\%20Green\%20Architecture\%20today\%20 -\%20Ms\%20Madhumita\%20Roy.pdf [Accessed on 25 July 2019].

Sajap, A.S., Rozita, R.A., Noor Farikha, H. and Yaacob, A.W. (1999). Diversity of ground-dwelling insects in Ayer Hitam Forest Reserve. Pertanika Journal Tropical Agricultural Science, 22(2): 207-208.

Stepankova, R., Bihunova, M. and Kabai, R. (2012). Design Principles of Public and Recreational Areas in the Urban Environment. Nitra, Slovakia: Slovak University of Agriculture in Nitra.

The Irish Sports Council (2008). Classification and Grading for Recreational Trails. Dublin: The Irish Sports Council.

The Star Online (2015). Varsity's lofty goals for forest reserve. 3 May. Available at: https://www.thestar.com.my/news/education/2015/05/03/varsitys-lofty -goals-for-forest-reserve/ [Accessed on 25 July 2019].

UNESCO-UNEP (United Nations Educational, Scientific and Cultural OrganizationUnited Nations Environment Programme) (1994). International Environmental Education Programme. Environmental Education Series 42. Nairobi: UNESCOUNEP.

WWF (World Wide Fund for Nature) Malaysia. (2019). Forests. Available at: http:// www.wwf.org.my/about_wwf/what_we_do/forests_main/ [Accessed on 20 March 2019].

Yin, R.K. (1984). Case Study Research: Design and Methods. Beverly Hills, CA: Sage Publications.

Zaidah, Z. (2007). Case study as a research method. Jurnal Kemanusiaan, 9(Jun): $1-6$.

Zaimora, R. (2006). Pelaksanaan piawaian pembangunan fasiliti penginapan dalam kawasan hutan lindungan di Malaysia. MSc diss. Universiti Teknologi Malaysia. 